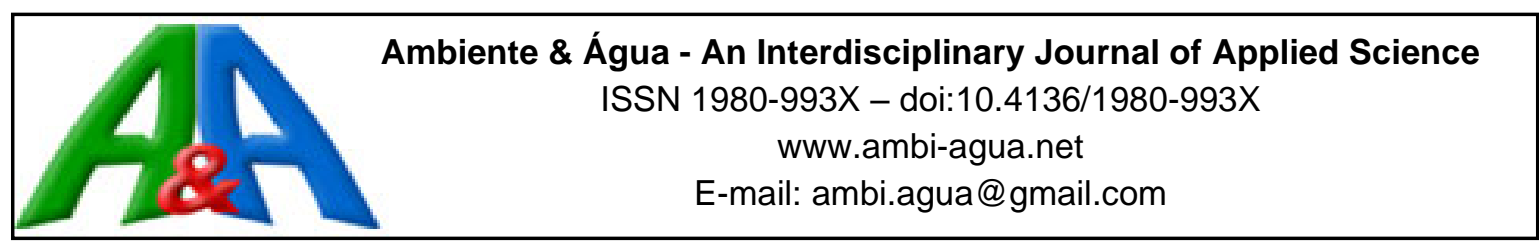

\title{
Reliability analysis as a support tool for projects focusing on non- potable uses of treated wastewater in steel industries
}

\author{
ARTICLES doi:10.4136/ambi-agua.2781
}

Received: 12 Aug. 2021; Accepted: 17 Dec. 2021

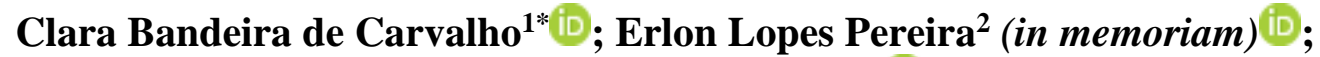 André Bezerra dos Santos 2 id}

\begin{abstract}
${ }^{1}$ Departamento de Engenharia Sanitaria e Ambiental. Universidade Federal do Ceará (UFC), Campus do Pici, Bloco 713, CEP: 60020-181, Fortaleza, CE, Brazil.

${ }^{2}$ Departamento de Engenharia Hidráulica e Ambiental. Universidade Federal do Ceará (UFC), Rua do Contorno, s/n, Bloco 713, CEP: 60451-970, Fortaleza, CE, Brazil. E-mail: erlonlopes@gmail.com, andre23@ufc.br

*Corresponding author. E-mail: clarabcarvalho1@gmail.com
\end{abstract}

\begin{abstract}
In a scenario of increasingly frequent water crises, the use of treated wastewater is an important water management tool, with quality standards being developed worldwide to ensure safety in such practices. In this context, it is necessary to guarantee the reliability of wastewater treatment plants (WWTP). Reliability has been used to predict the probability of reaching the established standards or determine the design concentrations required to achieve them. This study associated the reliability concept with the study of WWTP in the steel industry, focusing on water use. The method developed by Niku et al. (1979) and used by Oliveira and Von Sperling (2008) was used to determine the coefficient of reliability, the mean project concentrations, and the percentage of compliance with the parameters required by the legislation of 3 WWTPs that treat industrial effluents and 1 WWTP that treats sanitary effluent. The percentages of compliance with legislation for most parameters were equal to or close to $100 \%$, indicating an excellent performance of the 4 WWTPs, which could even allow the adoption of even higher levels of reliability. Therefore, the reliability studies together with a modeling of the contaminants' dispersion in the soil proved to be a very interesting approach for projects related to non-potable uses of treated wastewater in steel industries.
\end{abstract}

Keywords: reliability, soil disposal, water reuse.

\section{Análise de confiabilidade como ferramenta de apoio para projetos focando em usos não potáveis de águas residuárias tratadas em indústrias de Siderurgia}

\section{RESUMO}

Em um cenário de crises hídricas cada vez mais frequentes, o uso de águas residuárias tratadas (ART) aparece como uma importante ferramenta de gerenciamento hídrico, sendo desenvolvidos em todo o mundo padrões de qualidade a fim de garantir a segurança na utilização de ART. Nesse contexto, é preciso garantir a confiabilidade das estações de tratamento de esgoto (ETE). A confiabilidade vem sendo utilizada para prever a probabilidade de alcance dos padrões estabelecidos ou para determinar a concentração de projeto necessária para esse atingimento. O presente trabalho teve como objetivo a associação do conceito de 
confiabilidade ao estudo de ETEs de uma indústria siderúrgica, no tocante à produção de água para reúso. Para tanto, foi utilizado o método desenvolvido por Niku et al. (1979) e utilizado por Oliveira e Von Sperling (2008) para a determinação do coeficiente de confiabilidade, das concentrações médias de projeto e do percentual de atendimento aos parâmetros exigidos pela legislação de 3 ETEs que tratam efluentes industriais e 1 ETE que trata efluente sanitário. Os percentuais de cumprimento da legislação para a maioria dos parâmetros foram iguais ou próximos a 100\% indicando um excelente desempenho das 4 ETEs, podendo inclusive permitir a adoção de níveis de confiabilidade ainda mais elevados. Portanto, os estudos de confiabilidade em conjunto com a modelagem da dispersão de contaminantes no solo mostraram-se uma abordagem muito interessante para projetos relacionados ao uso não potável de águas residuárias tratadas em indústrias siderúrgicas.

Palavras-chave: confiabilidade, disposição no solo, reúso de água.

\section{INTRODUCTION}

In a scenario of increased water consumption across the planet, deterioration of water-body quality, and increased severity and frequency of water crises, the use of treated wastewater (TWW) proves to be an important water management tool (Sgroi et al., 2018; Capodaglio, 2020). Despite its importance, it is estimated that only 50\% of wastewater generated globally is treated, of which only $11 \%$ is reused (Jones et al., 2021).

The TWW reuse can be an option for various activities that, in many cases, have less restrictive standards than potable water. To enable the use, the TWW must achieve the required quality, attending to specific water standards, which vary according to the application. Treatment technologies have been studied and adopted to reduce the time between wastewater generation and the recovery of its quality. However, this can pose a safety issue for the water cycle, as the time to detect and respond to any failure is reduced (Capodaglio, 2020). A concept used in monitoring wastewater treatment plants (WWTPs) is reliability, which refers to the percentage of time during which TWW can reach established parameters (Alderson et al., 2015). Thus, a WWTP that always reaches the expected discharge values, which is the absence of performance failures, is considered $100 \%$ reliable (Alderson et al., 2015).

However, it is unlikely that a WWTP will not fail due to design and operation sensitivities and the variations in wastewater characteristics. Therefore, it is necessary to consider an acceptable failure probability, establishing a reliability level, such as the one developed by Niku et al. (1979), and known as the coefficient of reliability (COR). According to this method, the mean constituent concentration can be associated with the current legislation limits based on a probabilistic analysis.

Reliability studies are used to predict the probability of WWTPs in reaching established standards or determining the design or operation concentration necessary to establish a specific discharge pattern, which directly influences the capital and operational treatment costs (Lombard-Latune et al., 2018). Therefore, if a low probability of failure is desired, there is an increase in the treatment costs. In WWTPs that allow a greater risk of failure, costs become lower, making it necessary to quantify the tangible and intangible costs linked to the violation of legislative standards (Oliveira and Von Sperling, 2008).

Reliability studies were also developed by Oliveira and Von Sperling (2008), who analyzed the reliability of 166 WWTPs, investigating six treatment processes. Silveira (2011) analyzed the performance, efficiency, and reliability of treatment plants located in Fortaleza, Ceará, Brazil, to accomplish the discharge limits on surface water. In a similar objective, Alves et al. (2021) evaluated the reliability of stabilization ponds of 10 full-scale systems operating in Northeastern Brazil, finding that the $95 \%$ reliability scenario is not very feasible for these 
systems. The reliability concept can be used for different purposes. For instance, Alderson et al. (2015) investigated 56 large-scale WWTPs for TWW reuse in aquaculture and agriculture in Northeastern Brazil, including nine different and low-cost treatment technologies.

However, just a few studies associated the reliability analysis with water reuse patterns, especially with soil release. Predicting the percolating liquid behavior becomes an important tool since the contaminants present in the solution can be absorbed by plants in the soil and/or precipitates. Moreover, they may also leach into deeper soil layers, even generating environmental impacts and contamination risks (Basso and Kiang, 2017). This knowledge is especially relevant for sandy soils since these, in general, have low concentrations of organic matter and clay minerals that have greater ion exchange capacity than silts and sands. This characteristic represents a greater probability of groundwater contamination due to the high hydraulic conductivity and the low capacity to retain ions (Oliveira et al., 2010). The knowledge of soil physicochemical properties, proximity to underground aquifers, wastewater composition etc. can help decide the reliability level that a treatment plant will operate when a reuse project is conducted. Therefore, based on an assumed failure percentage, it is possible to calculate the concentration of effluent required, sometimes demanding process adjustments or step increments in the treatment plants.

This work conducted a reliability study of 4 steel-industry WWTPs, 3 for industrial effluents and 1 for sanitary effluents, in order to complement contaminant-mobility studies and evaluate the possibility of water reuse.

\section{MATERIAL AND METHODS}

\subsection{Study area and data survey}

The study used data from a steel industry located in Pecém, Ceará, Brazil. The industry produces around $359,000 \mathrm{~m}^{3} \mathrm{month}^{-1}$ of TWW with both industrial and sanitary characteristics. The generated wastewater is mainly from raw material yards, steelworks, continuous casting, cafeterias, and toilets treated in four WWTPs inside the industry. The steel industry provided the monitoring data for the years 2017 and 2018. The parameters and the analysis frequencies varied according to the treatment plant. The WWTPs, treatment processes, and the origin of TWW are shown in Table 1.

Table 1. WWTPs, wastewater origin, and treatment process.

\begin{tabular}{cccl}
\hline WWTP & Name & Wastewater origin & Treatment process \\
\hline Plate cooling & $\begin{array}{c}\text { WWTP } \\
1\end{array}$ & Plate cooling & $\begin{array}{l}\text { Reaction tank and thickener for clarification and removal } \\
\text { of fluorides }\end{array}$ \\
\hline $\begin{array}{c}\text { Raw material } \\
\text { yard }\end{array}$ & $\begin{array}{c}\text { WWTP } \\
2\end{array}$ & Raw material yard & Equalization, coagulation/sedimentation, and sand filters \\
\hline Principal & WWTP & $\begin{array}{c}\text { Multiple siderurgy } \\
\text { activities }\end{array}$ & Equalization, coagulation/sedimentation, and sand filters \\
\hline Sanitary & $\begin{array}{c}\text { WWTP } \\
4\end{array}$ & Sanitary wastewater & $\begin{array}{l}\text { Activated sludge of extended aeration and disinfection } \\
\text { with chlorine in a contact tank }\end{array}$ \\
\hline
\end{tabular}

\subsection{Parameters to water reuse}

The parameters adopted were those established by COEMA (Conselho Estadual de Meio Ambiente) Resolution 02/2017, from Ceará state, Brazil (COEMA, 2017). The standards adopted may vary according to the proposed use and current regulations.

For industrial WWTPs 1,2 and 3, the following parameters specified for TWW in metallurgical industries were analyzed: total chromium, hexavalent chromium, lead, cadmium, 
copper, nickel, soluble iron, total cyanide and free cyanide. Since among the possible uses for TWW is soil application, parameters whose limits were established in the resolution were also analyzed: $\mathrm{pH}$, temperature, and total suspended solids (TSS). Furthermore, the study also covered some elements whose knowledge is relevant to understanding soil behavior: aluminum, zinc, nitrate, and nitrite.

For WWTP 4 (Sanitary), aluminum, ammonia, BOD, thermotolerant coliforms, pH, TSS, and temperature were analyzed.

\subsection{Outliers removal and descriptive statistics}

A data procedure to remove outliers followed the methodology adopted by Silveira (2011), as shown in Equations 1 and 2.

$$
\begin{aligned}
& L_{\text {inf }}=Q_{\text {inf }}-1,5\left(Q_{\text {sup }}-Q_{\text {inf }}\right) \\
& L_{\text {sup }}=Q_{\text {sup }}-1,5\left(Q_{\text {sup }}-Q_{\text {inf }}\right)
\end{aligned}
$$

Where $\mathrm{L}_{\text {inf }}$ is the inferior limit, $\mathrm{L}_{\text {sup }}$ is the superior limit, $\mathrm{Q}_{\mathrm{inf}}$ is the inferior quartile, and $\mathrm{Q}_{\text {sup }}$ is the superior quartile.

An analysis based on descriptive statistics with the calculation of mean, median, maximum, minimum, standard deviation, and different percentiles was also developed. The values were used in the preparation of box-plot graphs.

\subsection{Reliability analysis}

In the reliability study, a lognormal distribution was assumed for all analyzed parameters. This distribution is considered the most adequate for most of the wastewater constituents (Alderson et al., 2015; Alves et al., 2021; Oliveira and Von Sperling, 2008).

The methodology was developed by Niku et al. (1979), and it was used by Oliveira and Von Sperling (2008) to calculate the coefficient of reliability (COR). Thus, the COR was obtained through the relationship between the coefficient of variation $(\mathrm{CV})$ and the standardized normal variable for a certain level of reliability $\left(\mathrm{Z}_{1-\alpha}\right)$, according to Equation 3 . To determine $\mathrm{Z}_{1-\alpha}$, a standardized relationship between this value and reliability $(1-\alpha)$ was used, as shown by other researchers (Orumieh et al., 2014; Oliveira and Von Sperling, 2008). COR was calculated for a $95 \%$ reliability level, a value pointed out in a study by Oliveira (2006) as adequate for the study of WWTPs. For this value, $\mathrm{Z}_{1-\alpha}$ is equal to 1.645 .

$$
C O R=\left(\sqrt{C V^{2}+1}\right) \cdot \exp \left[-Z_{1-\propto} \sqrt{\ln \left(C V^{2}+1\right)}\right]
$$

Where COR is the coefficient of reliability, CV is the coefficient of variation (standard deviation divided by the mean actual effluent value), and $\mathrm{Z}_{1-\alpha}$ is the reduced central normal variable corresponding to the probability of non-exceeding $(1-\alpha)$.

From the product of COR and the quality goals for reuse, the mean project concentrations were calculated for each parameter to reach the established limits. Then, the expected percentage of compliance to the adopted launch targets was calculated. In their work, Niku et al. (1979) proposed an equation derived from the probability density function integration of the normal distribution. However, other authors used relations between the normal and lognormal distributions to develop a simpler equation without performing this integration (Orumieh et al., 2014), represented by Equation 4. 
$Z_{1-\propto}=\ln (X s)-\frac{\left[\ln m_{x}-\frac{1}{2} \ln \left(C V^{2}+1\right)\right]}{\sqrt{\ln \left(C V^{2}+1\right)}}$

Where $m_{x}$ is the expected mean concentration of the constituent and Xs is the parameter set by legislation.

From the calculated value of $Z_{1-\propto}$, the NORMSDIST function in Microsoft Excel was used to obtain the value corresponding to the cumulative probability of the standardized normal distribution ( $Z$ distribution) and then determine the expected percentage of compliance with the established legislation standards for effluent discharge and reuse. The ability of treatment plants to produce wastewater with a mean concentration below discharge standards is proportional to the percentage of service achieved.

\section{RESULTS AND DISCUSSION}

\subsection{Descriptive statistics}

The 10, 25, 50, 75, and 90\% percentiles and the minimum and maximum values obtained for the parameters analyzed in industrial WWTPs 1,2, and 3 are represented in the box-plot in Figure 1. At the same time, the results for the sanitary WWTP 4, are shown in Figure 2.
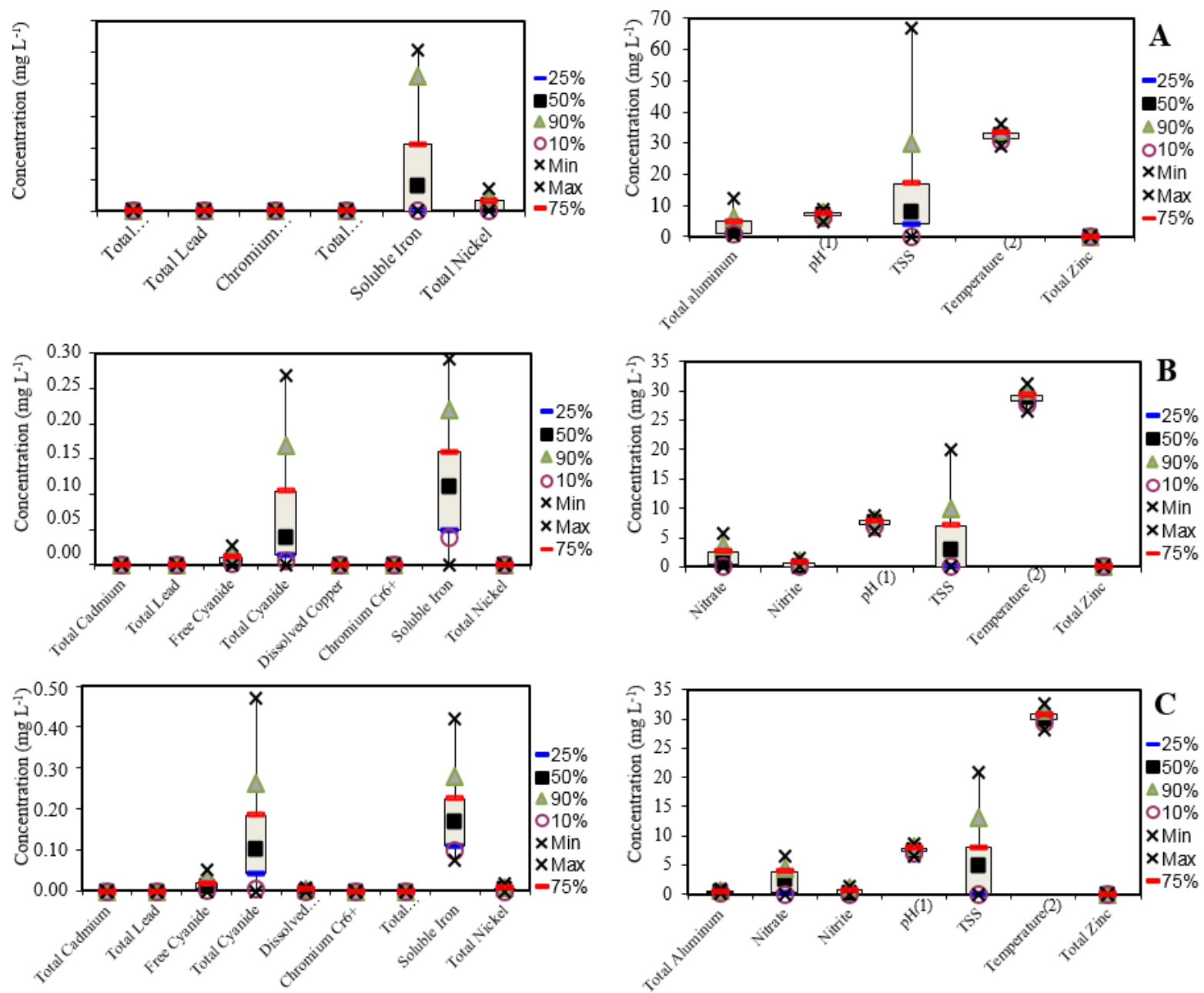

Figure 1. Concentration of analyzed parameters for the industrial WWTP 1 (A), WWTP 2 (B) and WWTP 3 (C).

(1) dimensionless parameter; (2) parameter unit is ${ }^{\circ} \mathrm{C}$. 


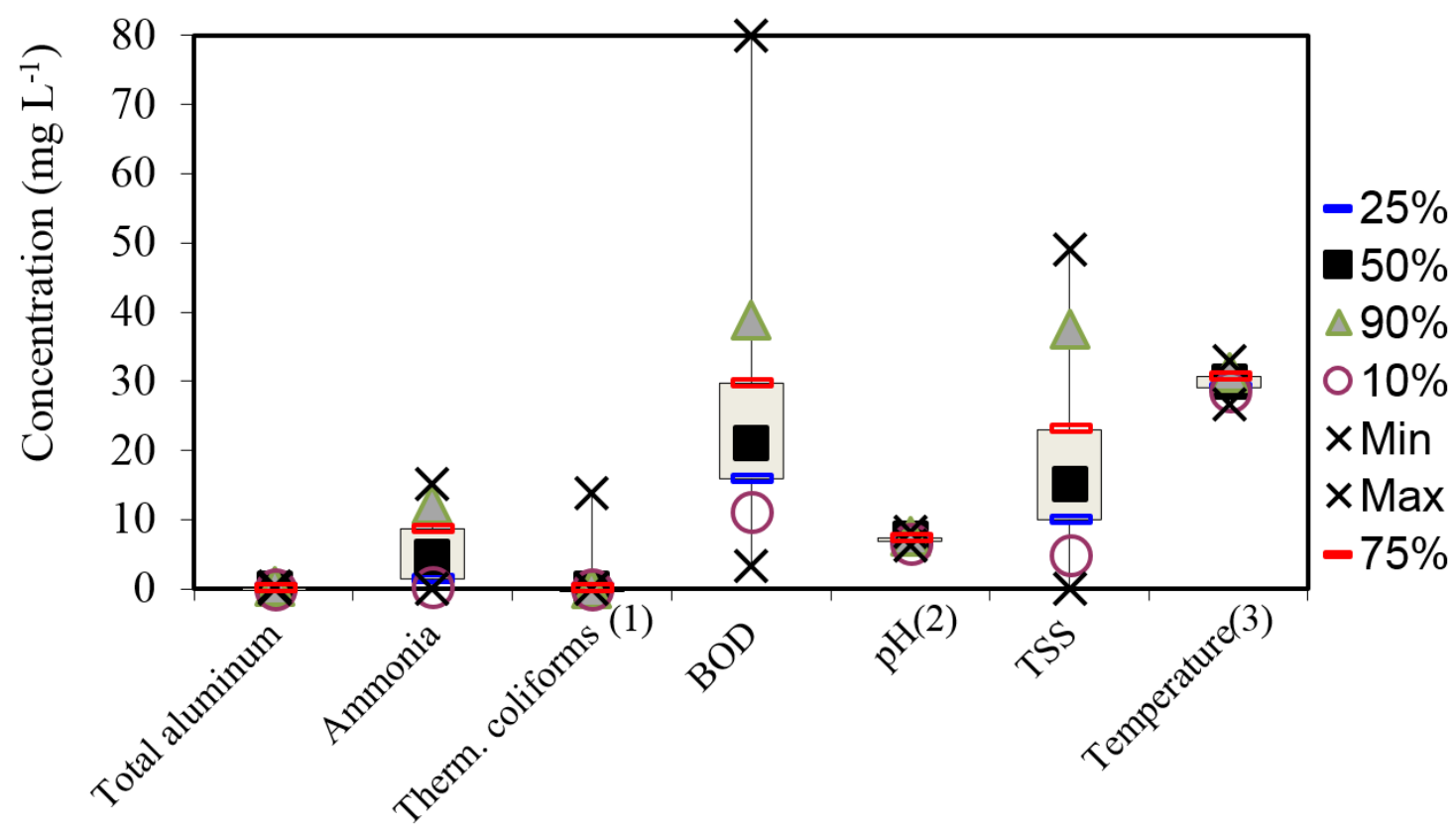

Figure 2. Concentration of analyzed parameters for the sanitary WWTP 4.

(1) parameter unit is MPN $100 \mathrm{~mL}^{-1}$; (2) dimensionless parameter; (3) Parameter unit is ${ }^{\circ} \mathrm{C}$.

In WWTP 1, free cyanide, total cyanide, dissolved copper, nitrate, and nitrite were not monitored. In turn, in WWTP 2, total chrome and total aluminum were not monitored. During the analyzed period, cadmium, lead, hexavalent chromium, and total chromium were not detected in the wastewater of WWTPs 1, 2, and 3. All parameters observed in this study for sanitary effluent were detected in WWTP 4 during the analyzed period.

\subsection{Reliability analysis}

The results of mean, standard deviation, CV, COR, expected mean, and percentage of compliance with legislation for the parameters required for metallurgical wastewater are shown in Tables 2 and 3, respectively. The industrial WWTPs 1,2, and 3 did not show the presence of cadmium, lead, hexavalent chromium, and chromium in the period analyzed. Therefore, these elements reached $100 \%$ of the legislation standards.

Although soils have a certain capacity to retain metals, the low concentration of heavy metals in wastewater is beneficial, since their accumulation can alter their bioavailability in the medium. How metals are found in the environment will determine their mobility, whether soil accumulation or leaching to groundwater. Heavy metals pose a relatively low toxicity risk while adsorbed to sediments. However, when exposed to living organisms, they represent a toxicity risk for humans, plants, and animals, being accumulated through the food chain (Azouzi et al., 2019; Miranda et al., 2021).

In soils with high retention capacity (usually clayey soils with high concentrations of organic matter), the main risk is heavy metal accumulation in the soil. In soils with low retention potential (usually sandy soils, such as those used in this study), the risk lies in leaching contaminants into groundwater. Sandy soils tend to show this trend due to their granular structure, which has more macropores, favoring water flow (Basso and Kiang, 2017).

It is thus understood that, in addition to knowing the behavior of treatment plants and TWW quality, it is important to have a full soil characterization. This factor becomes even more relevant in places where the regulation of wastewater use requires a specific quality and a maximum percentage of soil saturation by contaminants, which is the case of COEMA Resolution 02/2017. 
It is possible to notice variations between the $\mathrm{CV}$ and $\mathrm{COR}$ values for each parameter, which occur due to the different treatment technologies and the different wastewater origins. The lowest CV was obtained for temperature and $\mathrm{pH}$ in the three WWTPs evaluated, with the highest COR being obtained, ranging from 0.84 to 0.95 .

Overall, among the elements evaluated in Table 2, WWTP 1 presented the highest CV results, with COR in the range of $0.33-0.38$ for all parameters. Among the elements presented in Table 3, WWTP 2 had the highest CV. The high CV for metals is justified by the low concentration means of the components, smaller than the standard deviation. Such behavior does not reveal a bad treatment performance, just unstable operational levels, as previously observed (Alves et al., 2021). Since, for the same reliability level, higher CVs indicate lower COR, WWTPs in this situation will need to operate with lower design concentrations (Oliveira and Von Sperling, 2008). Because the effluent concentration values are below the legislation limits, even higher reliability levels could be applied if necessary (Alderson et al., 2015).

Table 2. Reliability analysis for dissolved copper, free cyanide, total cyanide, soluble iron, and nickel for the industrial WWTP 1,2, and 3.

\begin{tabular}{|c|c|c|c|c|c|c|}
\hline \multirow{2}{*}{ WWTP } & \multirow{2}{*}{ Statistics } & \multirow{2}{*}{$\frac{\text { Dissolved copper }}{\mathrm{mg} \mathrm{L}^{-1}}$} & \multirow{2}{*}{$\frac{\text { Free cyanide }}{\mathrm{mg} \mathrm{L}^{-1}}$} & \multirow{2}{*}{$\begin{array}{c}\text { Total cyanide } \\
\mathrm{mg} \mathrm{L}^{-1}\end{array}$} & \multirow{2}{*}{$\begin{array}{c}\text { Soluble iron } \\
\mathrm{mg} \mathrm{L}^{-1}\end{array}$} & \multirow{2}{*}{$\begin{array}{l}\text { Nickel } \\
\mathrm{mg} \mathrm{L}^{-1}\end{array}$} \\
\hline & & & & & & \\
\hline \multirow{6}{*}{1} & $\mu_{\mathrm{x}}$ & - & - & - & 0.0286 & 0.0044 \\
\hline & $\sigma_{x}$ & - & - & - & 0.0342 & 0.0039 \\
\hline & $\mathrm{CV}$ & - & - & - & 1.20 & 0.89 \\
\hline & $\mathrm{COR}$ & - & - & - & 0.33 & 0.38 \\
\hline & $\mathrm{m}_{\mathrm{x}}$ & - & - & - & 4.96 & 0.76 \\
\hline & $\mathbf{P} \%$ & - & - & - & 100 & 100 \\
\hline \multirow{6}{*}{2} & $\mu_{\mathrm{x}}$ & 0.00 & 0.082 & 0.0659 & 0.1187 & 0.00 \\
\hline & $\sigma_{x}$ & 0.00 & 0.0060 & 0.0667 & 0.0805 & 0.00 \\
\hline & $\mathrm{CV}$ & 0.00 & 0.73 & 1.01 & 0.68 & 0.00 \\
\hline & COR & 0.00 & 0.42 & 0.36 & 0.44 & 0.00 \\
\hline & $\mathrm{m}_{\mathrm{x}}$ & 0.00 & 0.08 & 0.36 & 6.59 & 0.00 \\
\hline & $\mathbf{P} \%$ & 100 & 100 & 100 & 100 & 100 \\
\hline \multirow{6}{*}{3} & $\mu_{\mathrm{x}}$ & 0.0017 & 0.0143 & 0.1210 & 0.1816 & 0.0037 \\
\hline & $\sigma_{x}$ & 0.0023 & 0.0123 & 0.0964 & 0.0897 & 0.0045 \\
\hline & $\mathrm{CV}$ & 1.35 & 0.86 & 0.80 & 0.49 & 1.22 \\
\hline & $\mathrm{COR}$ & 0.31 & 0.39 & 0.40 & 0.52 & 0.33 \\
\hline & $\mathrm{m}_{\mathrm{x}}$ & 0.31 & 0.08 & 0.40 & 7.76 & 0.66 \\
\hline & $\mathbf{P} \%$ & 100 & 100 & 100 & 100 & 100 \\
\hline \multicolumn{2}{|c|}{ Legislation limits } & 1 & 0.2 & 1 & 15 & 2 \\
\hline
\end{tabular}

Where $\mu_{x}$ is the distribution mean, $\sigma_{x}$ is the standard deviation, $\mathrm{CV}$ is the coefficient of variation, COR is the coefficient of reliability, $\mathrm{m}_{x}$ is the expected mean concentration of the constituent, and $\mathrm{P} \%$ is the expected percentage of compliance to COEMA Resolution 02/2017. 
Table 3. Reliability analysis for temperature, $\mathrm{pH}$, TSS, aluminum, nitrate, nitrite and zinc for industrial WWTPs 1,2 and 3.

\begin{tabular}{|c|c|c|c|c|c|c|c|c|}
\hline \multirow{2}{*}{ WWTP } & \multirow{2}{*}{ Statistics } & \multirow{2}{*}{$\frac{\text { Temperature }}{{ }^{\circ} \mathrm{C}}$} & \multirow{2}{*}{$\begin{array}{c}\mathbf{p H} \\
-\end{array}$} & \multirow{2}{*}{$\frac{\text { TSS }}{\mathrm{mg} \mathrm{L}^{-1}}$} & \multirow{2}{*}{$\frac{\text { Aluminum }}{\mathrm{mg} \mathrm{L}^{-1}}$} & \multirow{2}{*}{$\frac{\text { Nitrate }}{m g L^{-1}}$} & \multirow{2}{*}{$\frac{\text { Nitrite }}{\mathrm{mg} \mathrm{L}^{-1}}$} & \multirow{2}{*}{$\begin{array}{c}\text { Zinc } \\
\mathrm{mg} \mathrm{L}^{-1}\end{array}$} \\
\hline & & & & & & & & \\
\hline \multirow{6}{*}{1} & $\mu_{\mathrm{x}}$ & 32.5 & 6.99 & 13 & 3.20 & - & - & 0.03 \\
\hline & $\sigma_{x}$ & 1.3 & 0.75 & 13 & 3.04 & - & - & 0.03 \\
\hline & $\mathrm{CV}$ & 0.04 & 0.11 & 1.1 & 0.95 & - & - & 1.05 \\
\hline & $\mathrm{COR}$ & 0.9 & 0.84 & 0.4 & 0.37 & - & - & 0.35 \\
\hline & $\mathrm{m}_{\mathrm{x}}$ & 37.5 & - & 35 & 3.69 & - & - & 1.76 \\
\hline & P\% & 100 & - & 99.8 & 96.58 & - & - & 100 \\
\hline \multirow{6}{*}{2} & $\mu_{\mathrm{x}}$ & 28.8 & 7.56 & 4 & - & 1.68 & 0.39 & 0.004 \\
\hline & $\sigma_{x}$ & 0.8 & 0.52 & 5 & - & 1.73 & 0.48 & 0.005 \\
\hline & $\mathrm{CV}$ & 0.03 & 0.07 & 1 & - & 1.03 & 1.22 & 1.34 \\
\hline & COR & 0.95 & 0.89 & 0.3 & - & 0.36 & 0.33 & 0.31 \\
\hline & $\mathrm{m}_{\mathrm{x}}$ & 38.1 & - & 32.5 & - & 3.55 & 0.33 & 1.57 \\
\hline & P\% & 100 & - & 99.99 & - & 99.42 & 92.84 & 100 \\
\hline \multirow{6}{*}{3} & $\mu_{\mathrm{x}}$ & 30.4 & 7.65 & 5 & 0.49 & 2.26 & 0.45 & 0.008 \\
\hline & $\sigma_{x}$ & 0.9 & 0.43 & 5 & 0.19 & 1.93 & 0.50 & 0.006 \\
\hline & $\mathrm{CV}$ & 0.03 & 0.06 & 1.0 & 0.39 & 0.85 & 1.11 & 0.71 \\
\hline & COR & 0.95 & 0.91 & 0.4 & 0.58 & 0.39 & 0.34 & 0.43 \\
\hline & $\mathrm{m}_{\mathrm{x}}$ & 38.2 & - & 70 & 5.78 & 3.90 & 0.47 & 2.14 \\
\hline & P\% & 100 & - & 99.99 & 100 & 99.14 & 90.88 & 100 \\
\hline \multicolumn{2}{|c|}{ Legislation limits } & 40 & $5-9$ & 100 & 10 & $10^{(1)}$ & $1^{(1)}$ & 5 \\
\hline
\end{tabular}

(1) Parameter not evaluated for metallurgical wastewater according to COEMA Resolution $02 / 17$.

Where TSS is the total suspended solids.

The design concentrations $\left(\mathrm{m}_{\mathrm{x}}\right)$ obtained, values that guarantee that $95 \%$ of the data meet the legislation standards, in general, are above the actual concentrations of the parameters in the wastewater. The only exception is nitrite for WWTP 2, demonstrating a very good performance of the applied treatments. Such a result indicates that the parameters could meet more restrictive discharge standards than those currently considered (Oliveira and Von Sperling, 2008).

High expected percentages of compliance with the standards established by COEMA Resolution 02/2017 were obtained, with all the elements required for metallurgical industries with expected percentages of compliance of $100 \%$. Despite the greater range of variation of soluble iron compared to other parameters, it is expected that all results are within the limit of $15 \mathrm{mg} \mathrm{L}^{-1}$ established by legislation. As for the other elements evaluated in this work, only TSS, aluminum (in WWTP 1), nitrite, and nitrate did not reach 100\%. Despite not having reached $100 \%$, the percentages obtained for TSS were above 99\%, values much higher than those 
obtained in the WWTPs evaluated by Oliveira and Von Sperling (2008), Orumieh et al. (2014), and Alderson et al. (2015).

The wastewater composition is very broad. In this sense, for soils with low retention capacity, the elements' preference to be retained will depend on soil affinity and elements that are in greater availability (Carvalho et al., 2021). Thus, it is understood that, with the release of TWW with a low concentration of metals (as is the case with those previously evaluated), other elements present in higher concentration have a preference in the retention process in the soil, indicating possible leaching of these contaminants into groundwater.

Aluminum obtained an expected percentage of compliance of $96.6 \%$, with the limit of 10 $\mathrm{mg} \mathrm{L}^{-1}$ established by legislation. Although the element is not directly required for reuse application in the metallurgical industry, knowledge of it is important since aluminum can acidify the medium, releasing $\mathrm{H}^{+}$ions during hydrolysis (Shetty et al., 2021). The $\mathrm{pH}$ variation changes the soil cation exchange capacity, and the metals form in the environment. These elements are usually solubilized at low $\mathrm{pH}$, which increases their mobility, providing conditions that facilitate their leaching (Oliveira et al., 2010). Thus, for clayey soils with a predominance of negative charges, or soils with high organic matter concentrations, it is recommended to apply high levels of reliability to WWTPs to avoid medium saturation by this element.

For nitrite and nitrate, the percentage of compliance with legislation is not applicable for non-sanitary effluents since they are not parameters required by COEMA Resolution 02/2017 for the assessed wastewater. However, since these elements have little interaction with soil particles (Bolzani et al., 2012), with high mobility (Anami et al., 2008), knowledge of their behavior is relevant for determining soil and groundwater contamination risks. Thus, for these elements, when their use involves release in sandy soils, for which there is a greater tendency to runoff, it is necessary to use higher reliability levels to avoid groundwater contamination.

For WWTP 4, the results of mean, standard deviation, CV, COR, expected mean, and percentage of compliance with legislation for the parameters required for sanitary effluents and other analyzed parameters are presented in Table 4. It is possible to notice that the parameters with the highest $\mathrm{CV}$ values had the lowest COR. As in the previous results, the elements with the lowest $\mathrm{CV}$ were $\mathrm{pH}$ and temperature, with a $\mathrm{COR}$ of 0.91 and 0.94 , respectively.

Table 4. Reliability analysis for aluminum, ammonia, thermotolerant coliforms, BOD, pH, TSS, and temperature for sanitary WWTP 4.

\begin{tabular}{cccccccc}
\hline \multirow{2}{*}{ Statistics } & Aluminum & Ammonia & $\begin{array}{c}\text { Thermotolerant } \\
\text { coliforms }\end{array}$ & BOD & pH & TSS & Temperature \\
\cline { 2 - 7 } & $\mathrm{mg} \mathrm{L}{ }^{-1}$ & $\mathrm{mg} \mathrm{L}$ & MPN $100 \mathrm{~mL}^{-1}$ & $\mathrm{mg} \mathrm{L}^{-1}$ & - & $\mathrm{mg} \mathrm{L}^{-1}$ & ${ }^{\circ} \mathrm{C}$ \\
\hline$\mu_{\mathrm{x}}$ & 0.15 & 5.65 & 0.37 & 24 & 7.2 & 18 & 29.9 \\
$\sigma_{x}$ & 0.06 & 4.68 & 1.99 & 12 & 0.4 & 12 & 1.1 \\
$\mathrm{CV}$ & 0.42 & 0.83 & 5.40 & 0.5 & 0.1 & 0.7 & 0.04 \\
$\mathrm{COR}$ & 0.56 & 0.39 & 0.26 & 0.5 & 0.9 & 0.4 & 0.94 \\
$\mathrm{~m}_{\mathrm{x}}$ & 5.62 & - & 1320 & 61 & - & 45.0 & 37.7 \\
$\mathbf{P \%}$ & $\mathbf{1 0 0}$ & - & $\mathbf{9 9 . 8 3}$ & $\mathbf{9 9 . 9}$ & - & $\mathbf{9 9 . 9}$ & $\mathbf{1 0 0}$ \\
$\begin{array}{c}\text { Legislation } \\
\text { limits }\end{array}$ & 10 & - & 5000 & 120 & $5-9$ & 100 & 40 \\
\hline
\end{tabular}

The mean design concentrations were above the real means for all elements, indicating that the parameters would still meet more demanding limits, and higher reliability levels could be adopted.

All expected percentages of compliance with current legislation were above 99\%, except ammonia, which is not required by COEMA Resolution 02/2017, indicating good WWTP performance. 
The ammonia mean found in this study is lower than that obtained by Ponce et al. (2019) with the same technological route $\left(\mu_{\mathrm{x}}=14.08 \mathrm{mg} \mathrm{L}^{-1}\right)$, obtaining CV of 0.14 and COR of 0.77 . The large difference between the means obtained in the treatment $\left(\mu_{\mathrm{x}}=0.37 \mathrm{MPN} 100 \mathrm{~mL}^{-1}\right)$ and the design mean $\left(\mathrm{m}_{\mathrm{x}}=1320 \mathrm{MPN} 100 \mathrm{~mL}^{-1}\right)$ for thermotolerant coliforms indicates that the WWTP can meet more restrictive standards. This parameter had the highest CV (which is due to the microbiological indicator count varying according to many orders of magnitude) and the lowest COR value, as observed elsewhere (Alves et al., 2021).

For the same treatment technology, Oliveira and Von Sperling (2008) worked with BOD, whose $\mu_{\mathrm{x}}$ was $34 \mathrm{mg} \mathrm{L}^{-1}$ (higher value than that of this work), obtaining, at a reliability level of $80 \%$, COR of 0.40 , and a mean percentage of standard compliance (Xs $=60 \mathrm{mg} \mathrm{L}^{-1}$ ) greater than $80 \%$. For TSS, the authors obtained $\mu_{\mathrm{x}}$ of $35 \mathrm{mg} \mathrm{L}^{-1}$ and $\mathrm{m}_{\mathrm{x}}$ of $23 \mathrm{mg} \mathrm{L}^{-1}$, with a percentage of standard compliance close to $80 \%$. For the authors, the technological route was also the most efficient compared to other technologies.

Analyzing the treatment with facultative ponds, and with anaerobic ponds followed by facultative ponds and maturation ponds, Alderson et al. (2015) obtained, at a reliability level of $80 \%$, mean percentages of compliance with water reuse standards in agriculture and aquaculture of 29 and $79 \%$ for BOD, respectively, and 12 and 54\% for TSS.

In this context, the WWTP proved to be reliable, producing TWW with adequate quality for water reuse.

The reliability analysis tool can be applied with specific targeting according to the soil type and to the wastewater composition so that studies can define the contaminants of interest.

Sandy soils tend to have a lower retention capacity of pollutants than clayey soils. For the former, higher reliability levels should be adopted to avoid groundwater contamination. However, for clayey soils, the higher capacity to retain contaminants allows less restrictive reliability levels. Nonetheless, there is a need to monitor soil saturation limits.

In both cases, it is necessary to adopt soil management techniques since TWW application may induce groundwater contamination with a variety of pollutants. Examples of management techniques are: $\mathrm{O}$ horizon restoration with insertion of organic matter and maintenance of vegetation cover; waterproofing the launch area with geosynthetics; uses of localized irrigation systems to dispose of wastewater, as they reduce the risk of runoff and control water loss through deep percolation, reducing the mobility of contaminants (Carvalho et al., 2021).

\section{CONCLUSION}

In general, it was observed that the higher the coefficient of variation $(\mathrm{CV})$, the lower the coefficient of reliability (COR).

The percentages of compliance with legislation varied from 90 to $100 \%$ for all the parameters. Thus, there was an excellent performance of industrial and sanitary WWTPs, which could allow the adoption of higher levels of reliability.

Most of the mean design concentrations $\left(\mathrm{m}_{\mathrm{x}}\right)$ were below the limits allowed in COEMA Resolution 02/2017, even for high CV values found for some parameters, indicating that the adopted treatment technologies can produce TWW with adequate quality for non-potable reuse.

Thus, for sandy soils, for which there is a tendency to low contaminant retention capacity, it may be interesting to adopt higher reliability levels to avoid groundwater contamination. For clayey soils, the reliability levels can be less restrictive since there is a higher retention capacity for pollutants. However, the observance of possible soil saturation limits must be done.

Therefore, the reliability studies proved to be a very interesting approach for projects related to non-potable uses of treated wastewater in steel industries, being able to be an even better tool if associated with a modeling of the contaminants' dispersion in the soil.

Rev. Ambient. Água vol. 17 n. 1, e2781 - Taubaté 2022 


\section{ACKNOWLEDGMENT}

The authors acknowledge the financial support given by CNPq.

\section{REFERENCES}

ALDERSON, M. P.; SANTOS, A. B. DOS; MOTA FILHO, C. R. Reliability analysis of lowcost, full-scale domestic wastewater treatment plants for reuse in aquaculture and $\begin{array}{lllllll}\text { agriculture. Ecological Engineering, v. 82, } & \text { p. 6-14, } 2015 .\end{array}$ https://doi.org/10.1016/j.ecoleng.2015.04.081

ALVES, M. S.; SILVA, F. J. A.; CALDAS, A. L. C.; PEREIRA, E. L. Performance evaluation and coefficients of reliability for waste stabilization ponds in northeast Brazil. Revista Ambiente \& Água, v. 16, n. 1, 2021. https://doi.org/10.4136/ambi-agua.2571

ANAMI, M. H.; SAMPAIO, S. C.; SUSZEK, M.; GOMES, S. D.; QUEIROZ, M. M. F. Deslocamento miscível de nitrato e fosfato proveniente de água residuária da suinocultura em colunas de solo. Revista Brasileira de Engenharia Agrícola e Ambiental, v. 12, n. 1, p. 75-80, 2008. https://doi.org/10.1590/S1415-43662008000100011

AZOUZI, R.; CHAREF, A.; LAMIA, A.; KHADAR, S. Effect of Water Quality on Heavy Metal Redistribution and Mobility in Polluted Agricultural Soils in a Semi-Arid Region. Pedosphere, v. 29, p. 730-739, 2019. https://doi.org/10.1016/S1002-0160(17)60367-9

BASSO, J. B.; KIANG, C. H. Retardamento e dispersão hidrodinâmica de cobre, potássio e cloreto em solos residuais do subgrupo Itararé no Estado de São Paulo. Águas Subterrâneas, v. 31, n. 1, p. 117-133, 2017. https://doi.org/10.14295/ras.v31i1.28638

BOLZANI, H. R.; OLIVEIRA, D. L. A.; LAUTENSCHLAGER, S. R. Efeito da aplicação de água residuária de suinocultura no solo e na qualidade dos seus lixiviados. Engenharia Sanitária e Ambiental, v. 17, n. 4, p. 385-392, 2012. https://doi.org/10.1590/S141341522012000400005

CAPODAGLIO, A. G. Fit-for-purpose urban wastewater reuse: Analysis of issues and available technologies for sustainable multiple barrier approaches. Critical Reviews in $\begin{array}{lllll}\text { Environmental Science and Technology, p. 1619-1666, } 2020 . & \end{array}$ https://doi.org/10.1080/10643389.2020.1763231

CARVALHO, B. C.; PEREIRA, E. L.; DOS SANTOS, A. B. Mobilidade de contaminantes em solos arenosos após a aplicação de águas residuárias tratadas produzidas em indústria siderúrgica. Engenharia Sanitária e Ambiental, v. 26, n. 5, 2021. https://doi.org/10.1590/S1413-415220200339

CONSELHO ESTADUAL DO MEIO AMBIENTE (CE). Resolução n. 02 de 02 de fevereiro de 2017. Dispõe sobre padrões e condições para lançamento de efluentes líquidos gerados por fontes poluidoras. Diário Oficial [do] Estado, Fortaleza, 21 de fevereiro de 2017.

JONES, E. R.; VAN VLIET, M. T. H.; QADIR, M.; BIERKENS, M. F. P. Country-level and gridded estimates of wastewater production, collection, treatment and reuse. Earth System Science Data, v. 13, p. 237-254, 2021. https://doi.org/10.5194/essd-13-2372021

LOMBARD-LATUNE, R.; PELUS, L.; FINA, N.; L'ETANG, F.; LE GUENNEC, B.; MOLLE, P. Resilience and reliability of compact vertical-flow treatment wetlands designed for tropical climates. Science of the Total Environment, v. 642, p. 208-215, 2018. https://doi.org/10.1016/j.scitotenv.2018.06.036 
MIRANDA, L. S.; WIJESIRI, B.; AYOKO, G. A.; EGODAWATTA, P.; GOONETILLEKE, A. Water-sediment interactions and mobility of heavy metals in aquatic environments. Water Research, v. 202, 2021. https://doi.org/10.1016/j.watres.2021.117386

NIKU, S.; SCHROEDER, E. D.; SAMANIEGO, F. J. Performance of activated sludge processes and reliability-based design. Journal (Water Pollution Control Federation), v. 51, n. 12 , p. 2841- $2857,1979$.

OLIVEIRA, S. M. A. C. Análise de desempenho e confiabilidade de estações de tratamento de esgotos. 2006. 77 f. Tese (Doutorado em Saneamento, Meio Ambiente e Recursos Hídricos) - Universidade Federal de Minas Gerais, Belo Horizonte, 2006.

OLIVEIRA, S. M. A. C.; VON SPERLING, M. Reliability analysis of wastewater treatment $\begin{array}{llllllll}\text { plants. Water Research. } & \text { v. 42, } & \text { p. } & 1182 & - & 1194,\end{array}$ https://doi.org/10.1016/j.watres.2007.09.001

OLIVEIRA, F. C.; LEMKE-DE-CASTRO, M. L.; RODRIGUES, C.; BORGES, J. D. Adsorção e deslocamento do íon cádmio em solos do cerrado. Revista Brasileira de Engenharia Agrícola e Ambiental, v.14, n.8, p. 848-855, 2010. https://doi.org/10.1590/S141543662010000800009

ORUMIEH, H. R.; MARDAN, S.; MAZAHERI, R. Reliability Analysis of Waste Stabilization Pond under Iran's Climate Conditions. European Online Journal of Natural and Social Sciences, v. 3, n. 3, 2014.

PONCE, F. A. M.; ROLlEMBERG, S. L. S.; OlIVEIRA, A. G. Aplicação da análise de confiabilidade para avaliação de estações de tratamento de esgoto no estado do Ceará. Revista Tecnologia, v. 40, n. 2, 2019. https://doi.org/10.5020/23180730.2019.8971

SGROI, M.; VAGLIADASHI, F. G.A.; ROCCARO, P. Feasibility, sustainability and circular economy concepts in water reuse. Environmental Science \& Health, v. 2, p. 20-25, 2018. https://doi.org/10.1016/j.coesh.2018.01.004

SHETTY, R.; VIDYA, C. S. N.; PRAKASH, N. B.; LUX, A.; VACULIK, M. Aluminum toxicity in plants and its possible mitigation in acid soils by biochar: A review. Science $\begin{array}{lllll}\text { of The Total Environment, } & \text { v. } & 765, & \end{array}$ https://doi.org/10.1016/j.scitotenv.2020.142744

SILVEIRA, A. G. M. Análise de eficiência e confiabilidade em sistemas de baixo custo de tratamento de esgotos do tipo lagoas de estabilização. 2011. 108 f. Dissertação (Mestrado em Recursos Hídricos) - Universidade Federal do Ceará, Fortaleza, 2011. 